\title{
QUINTUPLE HELIX MODEL: INVESTMENT ASPECTS OF HIGHER EDUCATION IMPACT ON SUSTAINABILITY
}

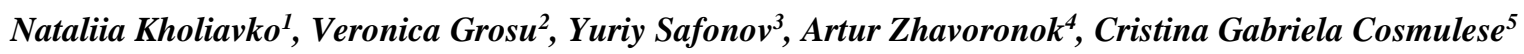 \\ 1 Dr. Sc., Associate Professor, Chernihiv Polytechnic National University. Address: 95 Shevchenko Str., 14035, \\ Chernihiv, Ukraine.Tel.+380666469599.E-mail: nateco@meta.ua \\ ${ }^{2}$ Dr. Sc., Professor, Stefan cel Mare University. Address: 13 Universitatii Str., 720229, Suceava, Romania. E-mail: \\ doruveronica@yahoo.it \\ ${ }^{3}$ Dr. Sc., Professor, Kyiv National Economy University Named After Vadym Hetman. Address: 54/1 Prospect \\ Peremogy, 03057, Kyiv, Ukraine. Address: 36, Metropolitan Vasil Lypkivsky Str., 03035, Kyiv, Ukraine. E-mail: \\ sum1971@ukr.net.
}

${ }^{4}$ PhD, Associate Professor, Yuriy Fedkovych Chernivtsi National University. Address: ddress: 2 Kotsyubynsky Str., 58012, Chernivtsi,Ukraine.E-mail: a.zhavoronok@chnu.edu.ua

${ }^{5}$ PhD, Assistant Professor, Stefan cel Mare University. Address:13 Universitatii Str., 720229, Suceava, Romania.

E-mail: gabriela.cosmulese@usm.ro

Received 2001 2021; Accepted 01032021

\begin{abstract}
The interdisciplinary analysis of sustainability requires an in-depth study of interactions between different economic entities, and identifying investment aspects of developing relations between them. The concept of Quintuple Helix Model allowed to analyze the interactions and mutual influence between universities, industry (business), government, civil society and the natural environment. Within the Quintuple Helix Model, the central role in the development of the economy is given to knowledge and their transfer between the various subsystems of the Model. The higher education subsystem occupies a special place in the Model because of such reasons: 1) within the educational activity, universities train highly qualified personnel for the national economy; 2) within the extracurricular activity, universities develop new green consciousness of the young generation that is crucial for further sustainable development of the national economy; 3) within the research activity, universities develop innovative regenerative technologies and environmentalfriendly technologies. Universities provide the generation, transfer and diffusion of sustainable knowledge in society and business. Synergy of higher education (universities), business (industry), government, public (civil society) is able to create a foundation for sustainable development of the national economy, increase the level of environmental protection, reduce the $\mathrm{CO}_{2}$ emissions, ensure rational use of exhaustive resources, create new green products and raise the standard of living of the country's population.
\end{abstract}

Keywords: higher education system, investment, Quintuple Helix Model, sustainability, Sustainable Development Goals.

JEL Codes: Q01; I25.

\section{Introduction}

Leading countries of the world in the last 15-20 years declare the need for comprehensive support for a sustainable way of the development of societies and economies. In 2015, all United Nations Member States adopted The Agenda-2030 for Sustainable Development. The Agenda-2030 identifies 17 Sustainable Development Goals (SDGs). These goals are aimed at the eradication of poverty, hunger, protection of

Copyright $\odot 2021$ Author(s), published by Vytautas Magnus University. This is an open access article distributed under the terms of the Creative Commons Attribution Non-Commercial 4.0 (CC BY-NC 4.0) license, which permits unrestricted use, distribution, and reproduction in any medium provided the original author and source are credited. The material cannot be used for commercial purposes. 
human rights, gender equality, qualitative education, sustainable use of nature, and development of sustainable and resilient cities, and promoting sustainable economic growth. The Agenda focuses on promoting innovation. In particular, SDG9 (Build resilient infrastructure, promote inclusive and sustainable industrialization and foster innovation) provides broad support for and promotion of research and innovation in the world, including in developing countries. Moreover, a plan was put in place to increase the number of R\&D employees and the public and private spending on science and innovation (General Assembly of United Nations).

It should be noted that in the XXI century, sustainability is a no alternative way of developing the world, which requires, first, the development and implementation of innovative approaches to the SDGs implementation; secondly, the reconciliation of stakeholder interests and deepening of relations between subjects of the government sector, business enterprise sector, higher education sector and representatives of civil society. Innovations and advanced partnerships make SDGs realistic and achievable. From a scientific point of view, it is important to examine the totality of interconnections and interactions that arise between stakeholders in the knowledge generation, transfer and commercialization of innovation in the real economy. On our opinion, the Quintuple Helix Model provides great opportunities for such research. Within the framework of this study, the Quintuple Helix Model was chosen as the methodological basis because of the following reasons:

1) the Model systemizes the relations between the subjects of 5 sectors (higher education sector, government sector, business sector, civil society, natural environment);

2) the Model allows to identify the interests of various stakeholders, and determine the areas of their mutually beneficial partnership;

3) the Model makes it possible to reveal the synergistic effects of the interactions of main stakeholders (higher education institutions, enterprises, government, civil society);

4) the Model is successfully used to analyze the prospects for innovative development of countries and regions based on the knowledge generation, and transfer of $R \& D$ results - therefore this makes it possible to extrapolate existing research to study the impact of higher education on sustainability (particularly, through the universities' educational activity, $\mathrm{R} \& \mathrm{D}$ results, commercialization of innovations, etc.);

5) the Model allows to complete a comprehensive analysis of the relationships and investment processes between main stakeholders;

6) the developers of the Model explored the possibility of its use in solving the problems of global warming - therefore the results of their study allow us to highlight the investment aspects of the impact of higher education on sustainability and focus on their in-depth study;

7) the academia (namely higher education sector, universities) occupies one of the central places in this Model.

Powerful capacity for sustainable development and SDGs' achievement is concentrated in the higher education system. Firstly, the educational activity of universities is accompanied by the dissemination of knowledge about sustainability in society, and the transfer of information about the prospects of sustainable development from the experienced professors to the younger generation of students. Secondly, within the universities research activities, the scholars carry out R\&D on the sustainable development, and transfer sustainable innovation to the economy. Thirdly, modern higher education institutions play an important role in the development of youth and local communities, and, correspondingly,

Copyright (C) 2021 Author(s), published by Vytautas Magnus University. This is an open access article distributed under the terms of the Creative Commons Attribution Non-Commercial 4.0 (CC BY-NC 4.0) license, which permits unrestricted use, distribution, and reproduction in any medium provided the original author and source are credited. The material cannot be used for commercial purposes. 


\title{
S sciendo
}

\author{
Management Theory and Studies for Rural Business and Infrastructure Development \\ eISSN 2345-0355. 2021. Vol. 43. No. 1: 111-128 \\ Article DOI: https://doi.org/10.15544/mts.2021.10
}

are able to have a significant impact on the promotion of sustainable ideas, concept, knowledge, consciousness, and green technologies.

However, successful implementation of university projects aimed at the certain SDGs' achievement requires additional funding. The mentioned above arguments prove the relevance of the study of investment aspects of the higher education impact on sustainable development. The use of the Quintuple Helix Model in the study has some advantages, as it provides an opportunity to conduct a comprehensive analysis of the diversified sources of funding for higher education institutions, namely: public funding (government sector); private investment, fee for the use of patented inventions and innovations (business enterprise sector); payment for educational services, endowment-funds (civil society), etc.

The purpose of the article is to investigate investment aspects of the higher education impact on sustainability within the framework of the Quintuple Helix Model.

\section{Literature review on helix models development}

The concept of Quintuple Helix Model is a logical development of the ideas of Etzkowitz (2008), Leydesdorff (2012), Carayannis and Campbell (2009). The Triple Helix Model (Figure 1) demonstrates the relationship between government, academia and industry at the intersection of their interests. Under this model, higher education institutions are seen as generators of innovation; enterprises (regardless of their size, scope, spheres and types of economic activity) - as generators and/or consumers of innovations. Transformation of the role of the public sector is envisaged, namely from the role of the controller to the role of the stimulant, which focuses on providing comprehensive support (including financial support) to innovatively active economic entities.

Copyright (C 2021 Author(s), published by Vytautas Magnus University. This is an open access article distributed under the terms of the Creative Commons Attribution Non-Commercial 4.0 (CC BY-NC 4.0) license, which permits unrestricted use, distribution, and reproduction in any medium provided the original author and source are credited. The material cannot be used for commercial purposes. 


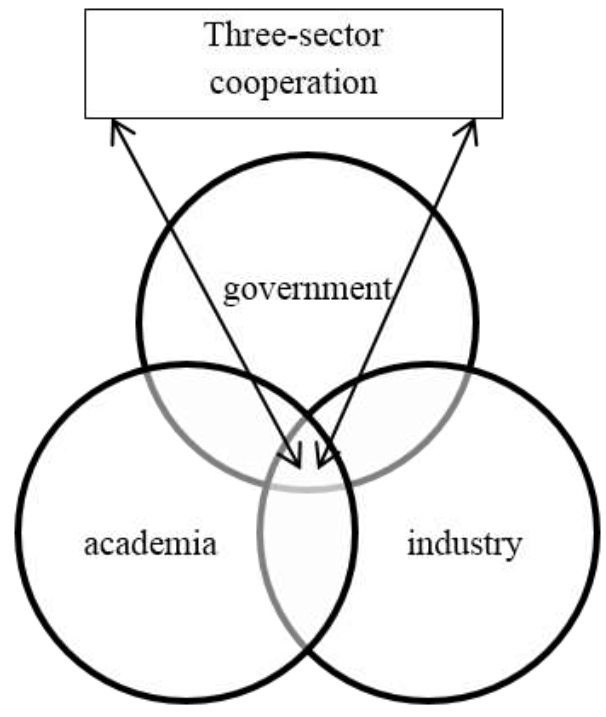

Figure 1. The Triple Helix Model (Etzkowitz, 2008; Leydesdorff, 2012)

At the same time the current social and economic situation in developed countries showed the necessity of development of the Triple Helix conceptual background. Woo (2014) argues that the Triple Helix model is not sufficiently sensitive to current challenges of the 21st century, which substantiates the feasibility of extending it to Quadruple Helix.

So 2009 the scientists Carayannis and Campbell (2009) in a series of collaborative works, defined the role of the civil society in the implementation of innovation processes. Moreover, representatives of civil society are seen as participants in innovation processes and as stewards / co-owners of the achieved results (Carayannis and Campbell, 2009; Carayannis and Campbell, 2012). Therefore the scientists formulated the concept of Quadruple Helix. Within the Quadruple Helix Model, sectors of government, entrepreneurship and higher education are complemented by the public sector (otherwise called "private non-profit sector"; civil society, etc.) - Figure 2.

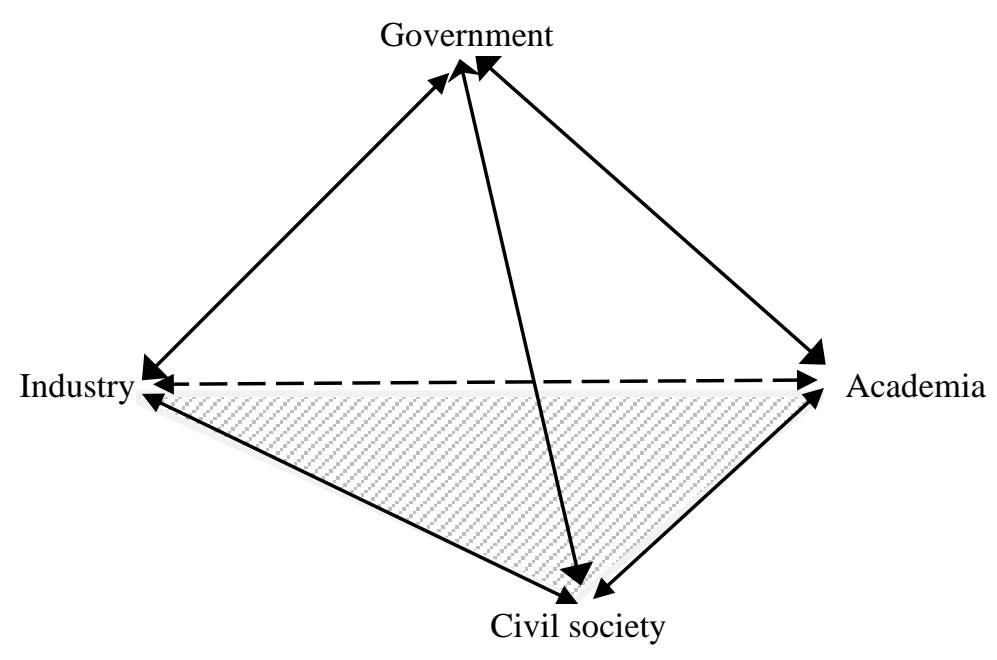

Figure 2. Schematic interpretation of The Quadruple Helix Model

Copyright (C) 2021 Author(s), published by Vytautas Magnus University. This is an open access article distributed under the terms of the Creative Commons Attribution Non-Commercial 4.0 (CC BY-NC 4.0) license, which permits unrestricted use, distribution, and reproduction in any medium provided the original author and source are credited. The material cannot be used for commercial purposes. 
Supporting the position of the scientists mentioned above, Yawson (2009) substantiates the importance of including the public sector in the Helix Model. This sector is analyzed by scientist not only as consumers of final products, but also as active actors within the national innovation system.

But the Quadruple Helix Concept is not permanent or static because it faces a numerous external challenges. Changes in the exogenous environment, globalization, and reorientation of the national economies of the leading countries towards sustainable development necessitated further development of helix models concepts. In 2012, Carayannis and Campbell singled out the Quintuple Helix Model. This modification of helix model includes a new element - the natural environment.

Thus, the following subsystems are distinguished and analyzed by scientists within the Quintuple Helix Model:

1) political subsystem - includes government, which defines strategic guidelines for the country's development, declares long-term priorities and develops tactical programs for their achievement; this subsystem covers the legal capital of a country, respectively, covering aspects of lawmaking in the fields of science, education, intellectual property, knowledge and technology transfer, as well as aspects of organizing and administering sufficient conditions to comply with applicable law;

2) economic subsystem - includes industry, companies, banks, enterprises (business enterprise sector); this subsystem covers the economic potential of the country, i.e. entrepreneurship, commodities, monetary system, available technologies and other means of labor;

3) educational subsystem - includes higher education system, academia, universities and other higher education institutions; in the Model, this subsystem is central, as it forms and develops human capital of the country; the power of the educational subsystem is justified by the fact that universities concentrate the nation's core intellectual capital, represented by scholars, researchers, professors, teachers, students;

4) cultural subsystem - includes media - and culture-based public, civil society, nongovernmental organizations in the educational and scientific spheres, private non-profit sector of national economy; this subsystem combines social and informational capital of the country (social capital means traditions, mores and values of citizens; information capital means communication between people, also through the social networks);

5) natural subsystem - includes resources, biota (flora and fauna) and other elements forming the natural capital of the country; in the process of studying the sustainability this exactly subsystem is decisive (Carayannis et al, 2012).

In our research we believe that the Quintuple Helix Model is the most applicable for the interdisciplinary study of theoretical and applied aspects of the impact intensification of higher education on sustainability. In the Quintuple Helix Model, the central role in the development of the economy and society is given to knowledge and their transfer between the various subsystems of the Model. The effective 
knowledge transfer requires highly developed legal frameworks and appropriate investment of higher education. The higher education subsystem occupies a special place in the Model, because of the following aspects:

within the educational activity, universities train highly qualified personnel for the national economy;

- within the extracurricular activity, universities develop new green consciousness of the young generation that is crucial for further sustainable development of the national economy;

- within the research activity, universities develop innovative regenerative technologies and environmental-friendly technologies. Higher education institutions provide the generation, transfer and diffusion of sustainable knowledge in society and business.

\section{Literature review on higher education impact on sustainability}

The focus of this article is on the study of the impact of investment processes in higher education on sustainable development. There are a number of publications in the scientific literature devoted to the study of the correlation between the volume of investment in education and the rate of economic growth. In particular, these are the papers of Schultz (1961), Benos et al. (2014), Teixeira et al. (2016), Sylwester (2000), Ganegodage et al. (2011), Mercan et al. (2014), Mariana (2015), etc. These scientists reveal various aspects of the higher education impact on economic growth and identify the specifics of this impact in different countries from various regions of the world.

At the same time, there are relatively few scientific articles that analyze the relationship between higher education and sustainable development, as this topic is new and not well studied. Montenegro de Lima et al. (2020) conducted a literature-based review; they analyzed 745 papers and identified five clusters of existing research: sustainability competences, sustainability science, campus greening, co-creation and transfer of knowledge, sustainability in university curricula. Thus, this review confirms the incomplete coverage of the aspects the impact of investment in higher education on sustainable development in the scientific literature.

Son-Turan (2020) proposed a higher education funding system that removes barriers to sustainable development and requires the broad engagement of stakeholders. In our opinion, the implementation of the proposed model would contribute to the achievement of several SDGs. The results of study of Son-Turan (2020) have made the basis of our research.

The specific of impact of educational investment for sustainable economic growth in some regions of China was studied by Liao et al. (2019). The authors concluded the following: 1) the existence of feedback causality between the education and the sustainable economic growth; 2) the local investment in education has a positive effect on the rate of sustainable economic growth. The research of $\mathrm{Yu}$ et al. (2017) also highlighted the regional aspects of correlation between investment in education and sustainability in China.

Numerous papers are devoted to the problematics of the sustainability in higher education. For example, Jenny $\mathrm{Su}$ et al. (2010) substantiated national policies and incentives that were funded to support sustainable development of higher education in Taiwan. In particular, the researchers analyzed practical cases and identified practical and educational aspects of the higher education impact on sustainability. Liu et al. (2020) studied the mechanism by which public universities fund campus sustainability projects in China. The authors noted the dominant role of state ministries in funding the university programs on sustainability.

Copyright (C) 2021 Author(s), published by Vytautas Magnus University. This is an open access article distributed under the terms of the Creative Commons Attribution Non-Commercial 4.0 (CC BY-NC 4.0) license, which permits unrestricted use, distribution, and reproduction in any medium provided the original author and source are credited. The material cannot be used for commercial purposes. 


\section{Management Theory and Studies for Rural Business and Infrastructure Development \\ eISSN 2345-0355. 2021. Vol. 43. No. 1: 111-128 \\ Article DOI: https://doi.org/10.15544/mts.2021.10}

Thus, the literature review has shown that previous research reveals some aspects of the higher education impact on sustainability, namely: institutional, educational (students' competences and green consciousness), economic, financial, reginal ones. However, the impact of investment aspects of the higher education impact on sustainability is still not well studied.

\section{Methods and Materials}

The methodological background of our research formed with the following theoretical concepts:

1) Triple Helix Model (developers Etzkowitz and Leydesdorff);

2) Quadruple Helix Model (developers Carayannis and Campbell);

3) Quintuple Helix Model (developers Carayannis, Barth, Campbell, Leydesdorff).

These are conceptual models, which theoretical basis is drawn on the stakeholder's engagement approach. The mentioned above concepts are detailed in research papers, published by their developers in open access journals. In our paper, an attempt is made to apply analytically the Quintuple Helix Model to solving the problem of the sustainable development of society and ensuring sustainable economic growth.

Conducting our research we used the following scientific methods:

- analysis method - at studying the scientific papers devoted to the conceptual framework of helixes models;

- synthesis method - at integrating the results of previous research of helixes models;

- methods of abstraction and modeling - at implicating of helixes models to the issues of the higher education impact on sustainability.

In our study, we formulated the following hypotheses:

$H 1$ : conducting an interdisciplinary and comprehensive study of sustainability is possible within the framework of the Quintuple Helix Model;

$H 2$ : higher education as an integral part of the Quintuple Helix Model is able to have a strong positive impact on sustainable development of the country;

H3: financial support for the higher education system determines the extent of its impact on the country's sustainability;

H4: intensification of the impact of higher education on sustainability requires the diversification of sources of the university investment (public funding, private investment, international funds, endowment funds, etc.).

The methodology of the conducted research is organized as follows. Section 1 is devoted to the reveal of the evolution of scientific concepts of helixes models. Section 2 presents the results of study of communication channels within the Quintuple Helix model, and the identification of role of the Quintuple Helix model's subsystems in ensuring sustainability. Section 3 contains the authors' interpretation of specificity of influence of higher education on sustainability (on the basis of the Quintuple Helix model).

\section{Results. Communication Channels within the Quintuple Helix Model}

The interaction of Quintuple Helix Model subjects is implemented through several channels (Figure 3). 


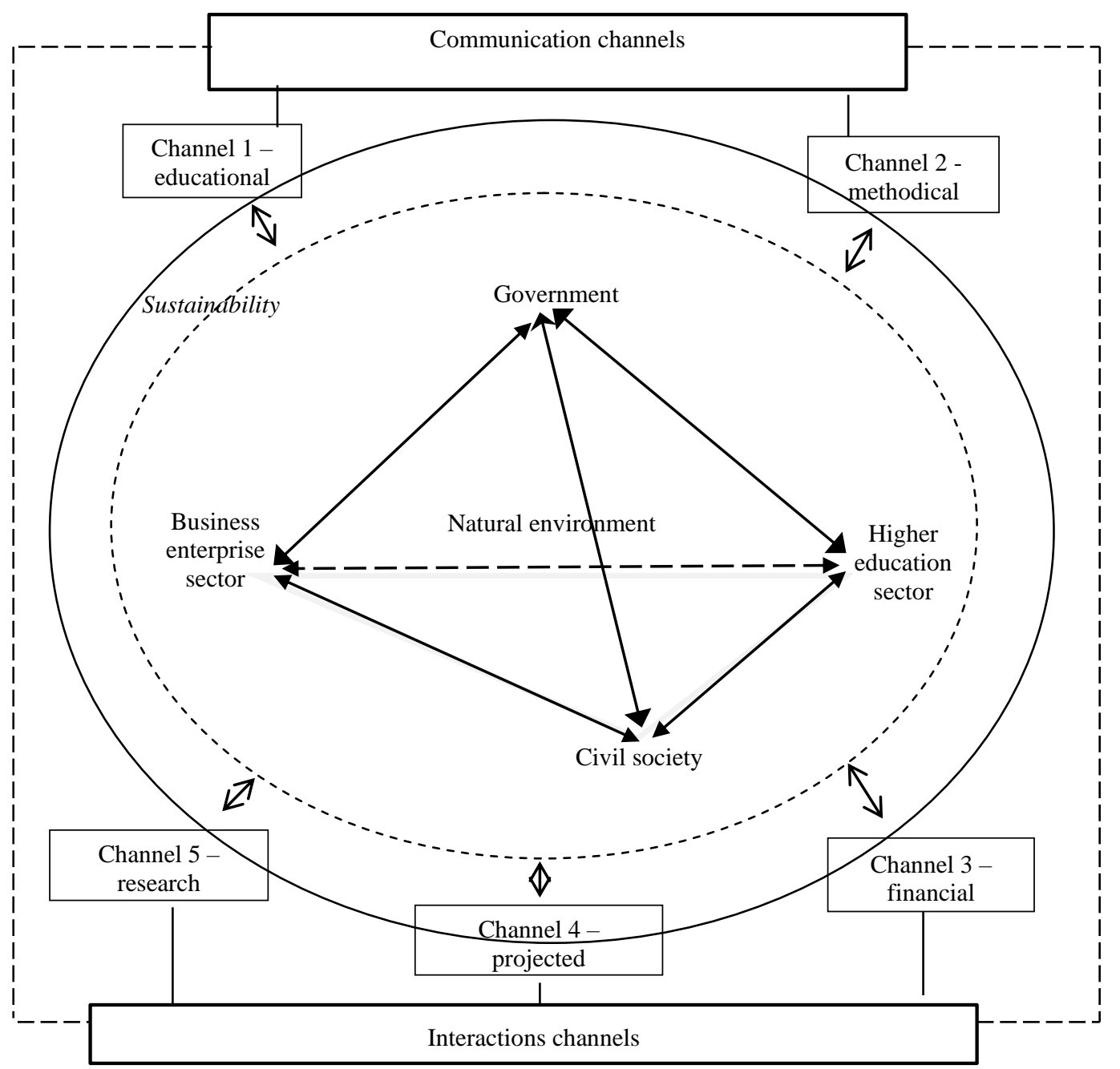

Figure 3. Scheme of communication channels within the Quintuple Helix Model

These channels are traditional, typical of most countries of the world and can be used at different levels of the stakeholders' engagement. The short characteristic of the communication channels:

- channel 1 - educational - formation of orders for training, retraining and advanced training of personnel in higher educational establishments; organizing internships for academic staff of universities at partner enterprises; organization of the educational process by universities in accordance with the current demands of employers and the labor market; involvement of entrepreneurs, civil servants, civic activists in conducting workshops or lectures for students;
- channel 2 - methodic - participation of public, business and public sector entities in the development of university education programs, student internship programs and internships, as well as educational standards; guarantee of high quality of educational services of universities; public and state monitoring of the quality of educational services; ensuring the flexibility of educational content, prompt updating of the content of educational programs in line with the transformation of labor market demands;

- channel 3 - financial - financing activities of universities in the fields of education, research, innovation, and international activity; creating of universities

Copyright ( 2021 Author(s), published by Vytautas Magnus University. This is an open access article distributed under the terms of the Creative Commons Attribution Non-Commercial 4.0 (CC BY-NC 4.0) license, which permits unrestricted use, distribution, and reproduction in any medium provided the original author and source are credited. The material cannot be used for commercial purposes. 


\title{
Sciendo
}

\author{
Management Theory and Studies for Rural Business and Infrastructure Development \\ eISSN 2345-0355. 2021. Vol. 43. No. 1: 111-128 \\ Article DOI: https://doi.org/10.15544/mts.2021.10
}

endowment funds; financing of the infrastructure development (research, innovation, information); diversification of funding sources for higher education institutions;

- channel 4 - project - joint development by stakeholders of all Quintuple Helix Model subsystems of investment, innovation, business projects (including international scientific and technical support projects, as well as start-up projects); initiation and implementation of social entrepreneurship projects together with representatives of civil society;

- channel 5 - research - participation of representatives of business, state and public sectors in conducting research together with higher education institutions (possible forms of stakeholders' participation: investment, cofinancing, initiation, development of feasibility studies and estimates for scientific projects, joint implementation of scientific projects, implementation of certain types of work within the framework of scientific projects under subcontracting; stakeholders' collaboration in the commercialization of research findings.

\section{Role of the Quintuple Helix Model's Subsystems in Ensuring Sustainability}

Knowledge is the foundation of the Quintuple Helix model. Knowledge transfer between the actors in this model determines the ability of the economic system to generate innovation, including those aimed at achieving SDGs. Accordingly, activities of all subjects of the Model, on the one hand, are related to the provision of knowledge and information; on the other hand, it is dependent on innovation and the rate of diffusion in an exogenous environment. In general, it can be stated that within the Quintuple Helix Model, sustainable development is determined by the efficiency of knowledge transfer and the possibility of their transformation into innovation.

The Quintuple Helix Model allows us to analyze changes in the roles played by different sectors of society in the context of its transition to sustainability (Figure 4). This Model not only reveals specifics of stakeholders' interactions, but also identifies areas of intersection of their interests. Let us analyze this through the lens of the concept of sustainable development and identify the main synergistic effects obtained by partners at the macro-, meso- and microeconomic levels.

\footnotetext{
Copyright @ 2021 Author(s), published by Vytautas Magnus University. This is an open access article distributed under the terms of the Creative Commons Attribution Non-Commercial 4.0 (CC BY-NC 4.0) license, which permits unrestricted use, distribution, and reproduction in any medium provided the original author and source are credited. The material cannot be used for commercial purposes.
} 


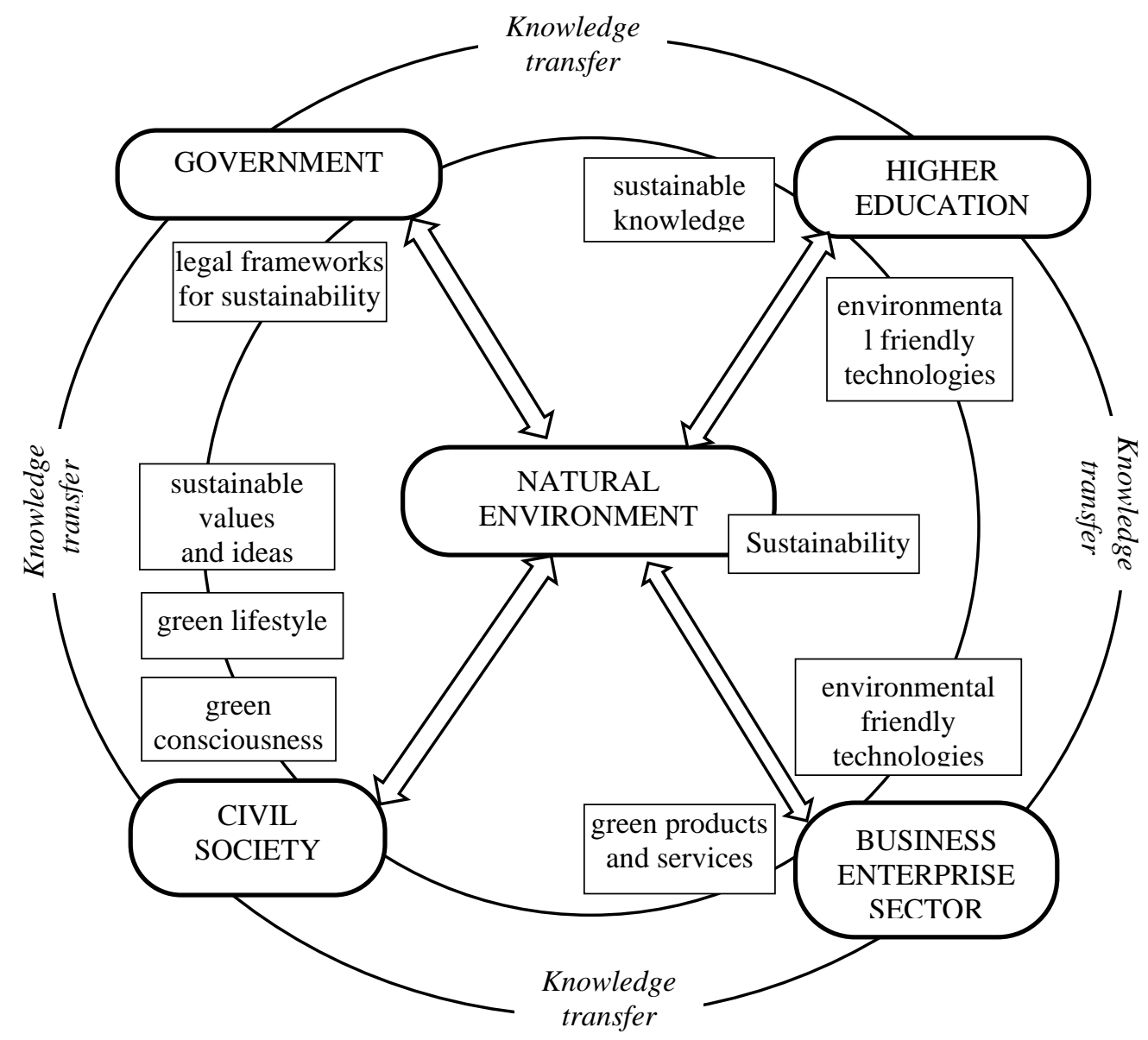

Figure 4. Conceptual scheme for promoting sustainable development by Quintuple Helix

Knowledge transfer enables the public sector to receive up-to-date information on the needs, interests and problems of citizens of the country, as well as inform about the level of satisfaction of the population with public policy. According to the Quintuple Helix Model, public sector entities need to move away from the regulatory and process controller positions and assume the role of an equal partner in order to ensure integrated sustainable development. Political subsystem of the Model reserves a monopoly right to adopt laws and other legal acts, which should be guided by:

- harmonization of the current legislation in the field of sustainable development with the provisions of the normative acts of the European Union;

- avoidance of contradictions and harmonization of all norms of legislation governing aspects of knowledge transfer and commercialization of innovations;

- elaboration and legalization of economic incentives for business and production rationalization and decrease of thon the environment;

- minimization of formal procedures (de-bureaucratization) and optimization of reporting on the scientific, technical and innovative activity of economic entities;

- removing obstacles to patenting and commercialization of intellectual property as a result of university research;

- guaranteeing the strict observance of the legislation in the field of protection of intellectual property rights, etc.

Among the main priorities of the public sector, we can point out the support for science-intensive industries, stimulation of innovation activity of economic entities, 


\author{
Management Theory and Studies for Rural Business and Infrastructure Development \\ eISSN 2345-0355. 2021. Vol. 43. No. 1: 111-128 \\ Article DOI: https://doi.org/10.15544/mts.2021.10
}

development of innovative policies, and development of innovative infrastructure. According to the SDGs, priority functions of the government within the Quintuple Helix Model include the reduction of inequality both domestically and between countries (SDG10) and promotion of Global Partnership for Sustainable Development (SDG17). Ensuring sustainability involves transforming the public sector into a link between academic science, university education, the public and business. The political subsystem of the Quintuple Helix Model has to develop the effective legal frameworks of sustainable development of the country (relevant regulations, programs, strategies, etc.). In line with pan-European trends, national and regional sustainable development strategies have been developed and implemented in developing countries in recent years. This is usually done through grant projects, with mentoring support from EU countries.

The Quintuple Helix model assumes a fundamentally new role for the business sector (first of all, we consider innovative and active, socially responsible businesses with long-term sustainable development strategies). In the context of sustainable development, businesses are viewed not so much as consumers of university education services and employers for their graduates, but as consumers of innovation and new knowledge. Collaboration between higher education institutions and businesses is able to create new values, develop new green products and services. Introduction of such innovative goods and services will increase the level of competitiveness of the enterprise.

Mechanisms of cooperation between business and universities should be flexible and diversified. The role of the business sector in such mechanisms can vary greatly:

1) enterprises as buyers of finished scientific, technical and innovative products developed by universities. In this type of business engagement, universities are often faced with marketing problems, have difficulties finding a buyer, and transform scientific developments into commercially attractive business offerings (accordingly, there is a risk that universities will not be able to offset research costs);

2) enterprises as customers of scientific, technical and innovative products and, accordingly, as investors of research works of institutions of higher education. In this case, universities have difficulties finding an investor who needs to be convinced of the prospect and return on investment in research;

3 ) enterprises as partners, co-executors and co-investors of university research innovation generation. In this case, universities in developed countries should compete with $R \& D$ firms and companies' R\&D departments when engaging business partners. Universities of developing countries face the problem of low innovation activity of domestic businesses (this explains their low demand for university research results and, consequently, low private investment in research).

In the near future, we expect an increase in business interest in cooperation with higher education institutions. This is justified by the tendency towards sustainable development, within which the competitiveness of economic entities will largely be determined by the degree of their innovation, the scale of implementation of resource-saving and environmentally sound technologies.

Copyright ( 2021 Author(s), published by Vytautas Magnus University. This is an open access article distributed under the terms of the Creative Commons Attribution Non-Commercial 4.0 (CC BY-NC 4.0) license, which permits unrestricted use, distribution, and reproduction in any medium provided the original author and source are credited. The material cannot be used for commercial purposes. 
Thus, in the context of green economic growth, we must state gradual transformation of business entities into strategic partners of universities in the initiation and implementation of scientific and technical and innovation projects with the simultaneous combination of the roles of customer, cocontractor, consumer and investor.

The Quintuple Helix model takes into consideration the impact of the public sector, which is a collection of public and other nonprofit organizations which activities cover the matters of sustainable development and the achievement of global goals of sustainable development. The role of this sector in the Quintuple Helix Model is to spread values and ideas of sustainable development in society, promote green lifestyle among young people. The public sector forms the informational and cultural capital of the country.

Within the Quintuple Helix Model, we view the public sector comprehensively, not only by NGOs, but also by the population of the country, which can play in a variety of roles (including combining them):

- as consumers of goods and services produced by the business sector. In this role, public sector representatives are shaping the demand for innovative green products and green services;

- as consumers of educational services produced by the higher education sector. In particular, in the course of educational activities, universities develop new green consciousness in students, instill in young people a new green lifestyle, and impart sustainable valuesand ideas to them;

- as consumers of public goods produced by the public sector, as recipients of support under public social programs. At the same time, citizens of the country formulate a request for sustainable development of the national economy, implementation of environmentally safe production technologies.

Moreover, we view the population of the country as secondary beneficiaries of social and economic effects resulting from synergistic interaction between business, government, the public and nature.

Taking into consideration contemporary social, economic, environmental, political, democratic tendencies, further existence of a society depends directly on the level of perception of its members under principles of sustainable development. In our opinion, the Quintuple Helix Model opens up opportunities for exploring a new phase of the co-evolution of nature and humanity. The synergy of partnerships from different sectors of society promotes sustainable development based on knowledge transfer and innovation.

\section{Impact of Higher Education on Sustainability}

Helix Models analyzed above are based on knowledge transfer and diffusion of innovation (Carayannis, Barth, Campbell, 2012; Oscar, Monterino, Thomshon, 2010). Higher education institutions are the drivers of progress in these Models. Modern universities in their activities are not limited to the transfer of knowledge to students. They also serve as knowledge generators, developers of innovations and new technologies. In general, we consider the higher education system as a driving force for knowledge-based sustainable development of the state and economy. However, the effective implementation of the functions assigned to the educational system requires the proper investment of university activities.

The analysis of the higher education's contribution in sustainability can be structured in the context of the main activities of universities. In carrying out their educational activities, universities provide training for:

1) future highly qualified people who can think innovatively, work with modern information and communication technologies and put into practice new sustainable knowledge (SDG4). Universities form the human capital of a country that can be

Copyright (C) 2021 Author(s), published by Vytautas Magnus University. This is an open access article distributed under the terms of the Creative Commons Attribution Non-Commercial 4.0 (CC BY-NC 4.0) license, which permits unrestricted use, distribution, and reproduction in any medium provided the original author and source are credited. The material cannot be used for commercial purposes. 


\section{Management Theory and Studies for Rural Business and Infrastructure Development \\ eISSN 2345-0355. 2021. Vol. 43. No. 1: 111-128 \\ Article DOI: https://doi.org/10.15544/mts.2021.10}

described as eco-oriented personnel (Polishchuk et al., 2019). Moreover, the above applies to both domestic and international students. Accordingly, there is a positive impact of higher education on sustainability both at regional and at global level;

2) a new generation of entrepreneurs who are able to pursue their business interests in an environmentally sensitive way. This is a generation of entrepreneurs that cares about the environment, is ready to invest in the development of new green technologies and spend financial resources to acquire them for implementation in the manufacturing process (SDG12). By creating new businesses, university graduates become self-employed, create new jobs, thus helping to improve the standard of living (SDG1, SDG2, SDG8).

Movement to achieve SDGs is possible only if there is, first of all, good qualitative legislation and guarantees of its continued compliance; second, sufficient funding. Funding for higher education on the residual basis allows universities to train future staff in typical, rather than innovative, methods; limits the possibility of updating the material and technical base, introduction of modern information and communication technologies in the educational process (Cosmulese et al., 2019).

Comparative analysis has shown that different approaches to financing higher education institutions are widespread in the world. The share of public funding for higher education in the OECD countries is average of $69 \%$ of the sector's total funding: the Czech Republic (79\%), Estonia (78\%), Slovakia (73\%), Poland (77\%), Russia (64\%), Latvia $(64 \%)$, etc. In the same time, business sectors of some countries play a significant role in universities' development. For example, the share of private funding in the South Korea is $29 \%$ of the sector's total funding, $22 \%$ - in Canada, 18 - in Israel, 16\% - in the United States of America, 14\% - in Japan, 14\% - in the Netherlands (Eurostat). By implementing their socially education work (as a rule within the extracurricular activity), universities provide:

1) development of green consciousness among young people that makes them more environmentally friendly and influences their future behavior as workers and / or businessmen (SDG16);

2) development of green lifestyle and healthy lifestyle of young people (SDG3);

3 ) formation of loyal attitude of youth to representatives of different races, cultures, religions; imparting gender equality principles (SDG5, SDG16).

In the conditions of limited funding for higher education, university professors have limited opportunities for extracurricular activities, which leads to a reduction in the positive impact on the education of fullfledged individuals with a well-formed character, an active life position, and an awareness of their capacity for selfrealization. Increasing investment in the activities of higher education institutions allows to expand the tools and range of forms of out-of-class work with young people, which will make them more interesting and attractive for students of different specialties. This will mean a more active involvement and, accordingly, a higher efficiency of the universities' activities to develop new sustainable values in youth.

The higher education makes an indirect

Copyright @ 2021 Author(s), published by Vytautas Magnus University. This is an open access article distributed under the terms of the Creative Commons Attribution Non-Commercial 4.0 (CC BY-NC 4.0) license, which permits unrestricted use, distribution, and reproduction in any medium provided the original author and source are credited. The material cannot be used for commercial purposes. 
impact on sustainability by carrying out research activity within which universities develop:

1) new environment-friendly technologies, regenerative technologies, the use of which will eliminate the negative impact of anthropological activity on the environment, in particular to optimize the exploitation of nature, reduce ecosystem pollution and overuse of natural resources (SDG14, SDG15);

2) new rational techniques and approaches to the use of scarce natural resources (SDG6);

3) cost-effective energy sources (SDG7) that will facilitate their wider implementation to ensure environmentally friendly production, reducing of $\mathrm{CO} 2$ emissions, diminishing climate change (SDG13);

4) innovative green products and services for business, capable of making businesses more competitive in their respective markets (SDG9);

5) sustainable knowledge and their transfer to society and in particular to the economy (SDG11).

It is important to emphasize that highquality research requires considerable investment. Because it involves the hiring of highly qualified $R \& D$ personnel, maintenance of research laboratories, up-dating of research equipment, development of research, innovative, informational infrastructures, purchasing of modern professional software, implementation of the latest information and communication technologies (Giesenbauer et al., 2020; Kholiavko et al., 2020). The necessity for substantial investment in $R \& D$ is recognized by governments and the business in number of countries. According to official statistics, more than 3\% of GDP in Germany is spent on $\mathrm{R} \& \mathrm{D} ; 1.86 \%$ - in Slovenia; $1.79 \%$ - in the Czech Republic; $1.29 \%$ - in Estonia; $1.2 \%$ - in Spain (EU-28 average - more than $2 \%$ of GDP). It is important to note that in the EU-28 more than $65 \%$ of $\mathrm{R} \& \mathrm{D}$ funding is investment from the business enterprise sector (75\% - Slovenia;
73\% - Hungary; 70\% - Bulgaria; 69\% Germany; $65 \%$ - Poland). On average in the EU-28 only $11 \%$ of R\&D costs are covered by the public sector (32\% - Romania; $28 \%$ Lithuania; 26\% - Latvia; 21\% - Slovakia) (Eurostat).

\section{Discussion}

Systematizing the above, we have to state the significant role of the educational subsystem of the Quintuple Helix Model in sustainable development of society and national economy. The educational and research activity of universities create preconditions for social and ecological transformation of economy and green economic growth. The R\&D results generated by the universities combine the aspects of cost-effectiveness and environmental protection when put into practice. In this context our research is correlated with the research results of Shkarlet et al. (2019). Besides similar research results have been achieved by Liao et al. (2019).

The problem of identification of investment aspects of higher education impact on sustainability raised in our paper is complex, since it covers the involvement of stakeholders from different sectors of the economy and society, as well as to determine their interests and priorities of cooperation. In this context we sustain the approach of Arnkil et al. (2010) who has formed four types of Helix Models, which were used within our research:

- Triple Helix Model, user-oriented generates consumer innovations based on the information they need; consumers are perceived as providers of information or as objects of innovations;

- Quadruple Helix Model, companyoriented - generates innovations based on existing or fundamentally new knowledge; consumers are perceived not only as informants but also as innovators;

- Quadruple Helix Model, government

Copyright (C) 2021 Author(s), published by Vytautas Magnus University. This is an open access article distributed under the terms of the Creative Commons Attribution Non-Commercial 4.0 (CC BY-NC 4.0) license, which permits unrestricted use, distribution, and reproduction in any medium provided the original author and source are credited. The material cannot be used for commercial purposes. 


\author{
Management Theory and Studies for Rural Business and Infrastructure Development \\ eISSN 2345-0355. 2021. Vol. 43. No. 1: 111-128 \\ Article DOI: https://doi.org/10.15544/mts.2021.10
}

sector-oriented - a focus on innovating public sector services; receiving feedback as a citizen response to innovation;

- Quadruple Helix Model, public-oriented - mostly theoretical; aimed at developing innovations by citizens of the country for the community, with the role of other sectors being reduced to supporting citizens as subjects of the innovation process.

Based on the results of our research, we consider it appropriate to supplement the analyzed above typing of Arnkil et al. (2010), with the "Quintuple Helix Model, natural environment oriented". In our opinion, it allows a deeper study of the features of the higher education impact on sustainability.

Nevertheless, regardless of the type of Helix Model, we absolutely agree with Carayannis and Campbell (2009), who insist on the hypothesis that investment in higher education generates additional impulses to create new sustainable knowledge, and find new effective ways of passing it on to the next generation.

Also we would like to highlight the research conducted by Oscar et al. (2010), Colapinto and Porlezza (2012). These scientists consider the Helix Model as the basis for the development of innovative activity in the country. This vision is in line with the approach of our research, which involves analyzing innovation as an integral aspect of sustainability. Exactly in this aspect we see one of the promising areas for further research of the specifics of the higher education impact on the countries' sustainable development (namely within the Quintuple Helix Model).

\section{Conclusions}

Thus, at the present stage of human development, there is a transformation of socio-economic relations and activities of key subjects of national economies towards more sustainable development. Governments of the leading countries of the world face the problem of ensuring economic growth and improving the standard of living of the population while avoiding the harmful impact of anthropogenic activity on the environment. Higher education plays a key role in promoting the country's sustainable development. In the context of building highqualify and sustainable economies, the higher education system can no longer exclusively act as a transmitter of information and knowledge from professors to students. Universities need to be transformed into knowledge generators, providers of innovative products and technologies, knowledge and information transfer entities. Full implementation of the potential of the educational subsystem of the Quintuple Helix Model requires the legislation development and guarantees of strict observance of its norms by all members of society, and also requires significant investment in university education and research. The Quintuple Helix Model opens up new opportunities for diversifying funding sources for higher education institutions, as sustainable development issues are relevant to all businesses and the public sector. The inflow of private investment into the higher education system will increase the efficiency of university activities and ensure rapid transfer of their innovative results to the real sector of the national economy. Proportions in

\footnotetext{
Copyright @ 2021 Author(s), published by Vytautas Magnus University. This is an open access article distributed under the terms of the Creative Commons Attribution Non-Commercial 4.0 (CC BY-NC 4.0) license, which permits unrestricted use, distribution, and reproduction in any medium provided the original author and source are credited. The material cannot be used for commercial purposes.
} 
funding higher education and research from different sources may vary; it depends on the level and pace of the country's economic development, investment and business activity in the country, development of university-business partnerships, the university's experience in commercializing $\mathrm{R} \& \mathrm{D}$ results in the real economy. The main focus should be on the gradual involvement of all stakeholders in addressing sustainable development issues and achieving global SDGs.

Summing, we consider it expedient to outline the authors' vision of the main policy and managerial implications. First of all, we emphasize that the effectiveness of the implementation of the recommendations and conclusions formulated in the paper directly depends on the degree of involvement of representatives of all sectors: higher education, business, government sector, and civil society. The role of the government in this process is the creating of favorable preconditions for such cooperation (economic, legal, political, social preconditions, etc.). At the national level, the international agreements and programs on the implementation of the Sustainable Development Goals (SDGs) must be ratified. The particular attention should be paid to the formation of a system of effective incentives for the development of collaboration between state bodies, business entities, universities and civil society in achieving the SDGs. Such incentives can be the following: targeted tax benefits for entities conducting $R \& D$, establishing R\&D companies; partial exemption from social security contributions; accelerated depreciation of the R\&D equipment, etc.

In our opinion, the management of stakeholders' cooperation in the implementation of SDGs does not require the creation of a new state regulatory body.
Functions related to the implementation of SDGs should be integrated into the functional field of existing regulating structures of relevant profile. However, at the national level should be developed the state programs for the implementation of SDGs in the country with an especial emphasis on the development of cooperation between stakeholders. It is advisable to prescribe the provisions on the implementation of SDGs in agreements (memorandums) on cooperation between universities, enterprises, NGOs and state/regional authorities.

Limitation of our research is the impossibility of conducting empirical research for practical confirmation of the effectiveness of the conclusions and recommendations formulated in the paper. This is primarily due to the novelty of the issues analyzed in the paper. Moreover, at the moment there is practically no relevant official statistics on this issue (in particular, retrospective data). On the one hand, this limitation complicated the research process; on the other hand, it revealed the priority directions of further research. Such directions include, firstly, the identification of promising tools for accumulation, processing, dissemination and transfer of information about the influence of education, state policy, business, and civil society on sustainable development; secondly, the organization of systematic monitoring of dynamics of relevant parameters both at the national and global levels.

Acknowledgments: This research is carried out within the framework of the scientific project "Integrated Model of Competitive Higher Education in Ukraine under the Quadruple Helix Concept" (grant of the Ministry of Education and Science of Ukraine; registration number 0117U007258).

Copyright (C 2021 Author(s), published by Vytautas Magnus University. This is an open access article distributed under the terms of the Creative Commons Attribution Non-Commercial 4.0 (CC BY-NC 4.0) license, which permits unrestricted use, distribution, and reproduction in any medium provided the original author and source are credited. The material cannot be used for commercial purposes. 


\author{
Management Theory and Studies for Rural Business and Infrastructure Development \\ eISSN 2345-0355. 2021. Vol. 43. No. 1: 111-128 \\ Article DOI: https://doi.org/10.15544/mts.2021.10
}

\title{
References
}

Arnkil, R., Järvensivu, A., Koski P., \& Piirainen, T. (2010). Exploring Quadruple Helix Outlining useroriented innovation models. Final Report on Quadruple Helix Research for the CLIQ project, under the Interreg IVC Programme. Retrieved from: https://trepo.tuni.fi/bitstream/handle/10024/65758/978-951-44-8209-0.pdf [28 10 2020]

Benos, N., \& Zotou, S. (2014) Education and economic growth: A meta-regression analysis. World Dev., 64, 669-689. https://doi.org/10.1016/j.worlddev.2014.06.034

Carayannis, E.G., \& Campbell, D.F. (2009). 'Mode 3' and 'Quadruple Helix': toward a 21st century fractal innovation ecosystem. International Journal of Technology Management, 46(3-4), 201-234. https://doi.org/10.1504/IJTM.2009.023374

Carayannis, E.G., Barth, T.D., \& Campbell, D.F. (2012). The Quintuple Helix innovation model: global warming as a challenge and driver for innovation. J InnovEntrep, 1, 2. https://doi.org/10.1186/2192-5372-1-2

Colapinto, C. \& Porlezza, C. (2012). Innovation in creative industries: from the quadruple helix model to the systems theory. Journal of the Knowledge Economy, 3(4), 343-353. https://doi.org/10.1007/s13132-011-0051-x

Cosmulese, C.G., Grosu, V., Hlaciuc, E., \& Zhavoronok, A. (2019). The Influences of the Digital Revolution on the Educational System of the EU Countries. Marketing and Management of Innovations, 3, $242-254$. https://doi.org/10.21272/mmi.2019.3-18

Etzkowitz, H. (2008). Triple Helix Innovation: Industry, University, and Government in Action, London and New York: Routledge. https://doi.org/10.1111/j.1435-5957.2011.00357.x

Ganegodage, K.R., \& Rambaldi, A.N. (2011). The impact of education investment on Sri Lankan economic growth. Economics of Education Review, 30, 1491-1502. https://doi.org/10.1016/j.econedurev.2011.08.001

Giesenbauer, B., \& Müller-Christ, G. (2020). University 4.0: Promoting the Transformation of Higher Education Institutions toward Sustainable Development. Sustainability, 12, 3371. https://doi.org/10.3390/su12083371

Jenny Su, H. \& Chang, T. (2010). Sustainability of higher education institutions in Taiwan. International Journal of Sustainability in Higher Education, 11 (2), 163-172. https://doi.org/10.1108/14676371011031883

Kholiavko, N., Djakona, A., Dubyna, M., Zhavoronok, A., \& Lavrov, R. (2020). The higher education adaptability to the digital economy. Bulletin of the National Academy of sciences of the Republic of Kazakhstan, 4(386), 294-306. https://doi.org/10.32014/2020.2518-1467.130

Leydesdorff, L. (2012). The Triple Helix, Quadruple Helix,.., and an N-tuple of helices: Explanatory models for analysing the knowledge-based economy? Journal of the Knowledge Economy, 3(1), 25-35. https://doi.org/10.1007/s13132-011-0049-4

Liao, L., Du, M., Wang, B., \& Yu, Y. (2019). The Impact of Educational Investment on Sustainable Economic Growth in Guangdong, China: A Cointegration and Causality Analysis. Sustainability, $11,766$. https://doi.org/10.3390/su11030766

Liu, L., \& Gao, L. (2020). Financing university sustainability initiatives in China: actors and processes. International Journal of Sustainability in Higher Education, 22(1), 44-58. https://doi.org/10.1108/IJSHE-11-2019-0333

Mariana, D.R. (2015). Education as a determinant of the economic growth. The case of Romania. ProcediaSocial and Behavioral Sciences, 197, 404-412. https://doi.org/10.1016/j.sbspro.2015.07.156

Mercan, M., \& Sezer, S. (2014). The effect of education expenditure on economic growth: The case of Turkey. Procedia-Social and Behavioral Sciences, 109, 925-930. https://doi.org/10.1016/j.sbspro.2013.12.565

Montenegro de Lima, C.R., Coelho Soares, T., Andrade de Lima, M., Oliveira Veras, M., \& Andrade Guerra, J.B.S.O.d.A. (2020). Sustainability funding in higher education: a literature-based review. International Journal of Sustainability in Higher Education, 21(3), 441-464. https://doi.org/10.1108/IJSHE-07-2019-0229

Oscar, A., Monterino, S., \& Thomshon, M. (2010). A Growth Model for the Quadruple Helix Innovation Theory. Journal of Business Economics and Management, 13 (4), 1-31. https://doi.org/10.3846/16111699.2011.626438

Polishchuk, Y., Kornyliuk, A., \& Britchenko, I. (2019). University as a core of e-learning ecosystem. Elearning: Unlocking the Gate to Education around the Globe 14th conference reader, Prague: Center for Higher

Copyright (C 2021 Author(s), published by Vytautas Magnus University. This is an open access article distributed under the terms of the Creative Commons Attribution Non-Commercial 4.0 (CC BY-NC 4.0) license, which permits unrestricted use, distribution, and reproduction in any medium provided the original author and source are credited. The material cannot be used for commercial purposes. 
Education Studies Location: Microsoft, Prague, Czech Republic Date: JUN 20-21, 309-319. Retrieved from: https://philpapers.org/archive/BRIBIU.pdf [24 12 2020]

Schultz, T.W. (1961). Investment in human capital. The American Economic Review, 5, 1-17. Retrieved from: https://www.jstor.org/stable/1818907 [23 11 2020]

Shkarlet, S., Kholiavko, N., \& Dubyna, M. (2019). Information Economy: Management of Educational, Innovation, and Research Determinants. Marketing and Management of Innovations, 3, 126-141. http://doi.org/10.21272/mmi.2019.3-10

Son-Turan, S. (2020). The HESFS for higher education funding, employment and sustainability. International Journal of Sustainability in Higher Education, 22(1), 100-119. https://doi.org/10.1108/IJSHE-10-2019-0310

Sylwester, K. (2000). Income inequality, education expenditures, and growth. Journal of Development Economics, 63(2), 379-398. https://doi.org/10.1016/S0304-3878(00)00113-9

Teixeira, A.A.C.. \& Queirós, A.S.S. (2016). Economic growth, human capital and structural change: A dynamic panel data analysis. Research Policy, 45(8), 1636-1648. https://doi.org/10.1016/j.respol.2016.04.006

Woo, P.H. (2014). Transition from the Triple Helix to N-Tuple Helices? An interview with Elias G. Carayannis and David F. J. Campbell. Scientometrics, 99, 203-207. https://doi.org/10.1007/s11192-013-1124-3

Yawson, R.M. (2009). The Ecological System of Innovation: A New Architectural Framework for a Functional Evidence-Based Platform for Science and Innovation Policy. The Future of Innovation Proceedings of the XXIV ISPIM 2009 Conference. Vienna, Austria. June 21-24. https://doi.org/10.31124/advance.7367138.v1

Yu, Z., Zhu, N. \& Baležentis, T. (2017). Impact of public education and regional economic growth in China: A shadow-price perspective. Sustainability, 9, 1333. https://doi.org/10.3390/su9081333

Copyright (C) 2021 Author(s), published by Vytautas Magnus University. This is an open access article distributed under the terms of the Creative Commons Attribution Non-Commercial 4.0 (CC BY-NC 4.0) license, which permits unrestricted use, distribution, and reproduction in any medium provided the original author and source are credited. The material cannot be used for commercial purposes. 